\title{
4. Positionsverb
}

Typologiskt kan språk delas in i två kategorier när det gäller lexikaliseringen av rörelse (motion events): satellite-framed respektive verb-framed languages. Skillnaden mellan germanska och romanska språk (till exempel franska, italienska och spanska) har ofta varit utgångspunkten för denna indelning (Talmy I985; 2000; Slobin I996; Ross 2016). Talmy använder termerna väg eller riktning (path) och sätt (manner) där exempelvis ett språk som italienskan som benämns verb-framed har rörelsens väg/riktning inherent $\mathrm{i}$ huvudverbet medan rörelsens sätt kan uttryckas med ett komplement. Germanska språk som svenska och nederländska är satellite-framed där istället rörelsens sätt finns inherent i huvudverbet medan rörelsens väg/riktning kan uttryckas med en satellit (till exempel en partikel eller postposition), jfr. nederländska i (4.I) med översättningarna till italienska i (4.2) och svenska i $(4 \cdot 3) .^{\mathrm{r}}$

(4.I) De mensen wandelen het gebouw uit.

(4.2) La gente esce dall'edificio. 'människorna går ut byggnaden'

(4.3) Människorna vandrar $u t$ ur byggnaden.

I exempel (4.2) anges riktning i verbets semantik (esce = gå ut) medan nederländska använder postpositionen uit och svenska adverbet $u t$ (i kombination med prepositionen $u r$ ) för att uttrycka riktning. I den nederländska satsen i (4.I) benämns uit postposition då den placeras sist i satsen och på så vis anger riktning. Svenskan använder istället riktningsadverb i kombination med en

Hur du refererar till det här kapitlet:

Johansson, A. 2019. Kontrastiva studier i nederländska och svenska: Med en inledning om tredjespråksinlärning och tvärspråklig medvetenhet. Pp. 56-77. Stockholm: Stockholm University Press. DOI: https://doi.org/IO.I6993/baz.e License: CC-BY. 
preposition i (4.3). Man kan alltså se att verbet i italienska anger generell rörelse (gå) och i nederländska specifik rörelse med verbet wandelen 'vandra' som alltså anger på vilket sätt rörelsen sker: gå till fots i lugnt tempo. Svenskans vandra har motsvarande betydelse. Om ett romanskt språk vill ange rörelsens sätt sker det med ett gerundium (verbalsubstantiv), prepositionsfras eller adverbial. I följande sats används prepositionsfras med flyget på italienska för att ange sätt på vilket rörelsen sker: sono andato a New York con l'aereo 'jag har åkt med flyget till New York'. På svenska och nederländska kan man använda verbet flyga där både rörelse och sätt anges: jag har flugit till New York respektive ik ben naar New York gevlogen.

Uppdelning av språk i satellite-framed och verb-framed kan även appliceras på bruket av positionsverb i germanska språk för att uttrycka befintlighet. Även här skiljer sig romanska respektive germanska språk åt i det att exempelvis franska uttrycker befintlighet (locative events) med generella verb såsom être 'vara', était posée 'vara placerad' eller se trouver 'befinna sig' medan de germanska språken såsom nederländska, svenska och tyska kan uttrycka befintlighet med verb som anger en specifik position med staan/liggen/zitten respektive stå/ligga/sitta (se till exempel Viberg 20I3). Nedan jämförs franskan i (4.4) med översättningar till nederländska och svenska i (4.5) respektive (4.6).

(4.4) Il est en prison. 'Han är i fängelset'

(4.5) Hij zit in de gevangenis.

(4.6) Han sitter i fängelse.

I (4.4) har den franska exempelmeningen ett generellt verb (vara) som uttrycker befintlighet medan de nederländska och svenska exempelmeningarna använder zitten respektive sitta som anger en specifik position där dock betydelsen egentligen inte behöver innebära att fången verkligen sitter utan snarare betydelsen att det mänskliga subjektet befinner sig i fängelset. Både svenska och nederländska har generella verb som uttrycker existens, till exempel har svenskan vara och finnas och nederländskan zijn. Dock används positionsverben mycket frekvent på ett sätt som inte är möjligt för de romanska språken. 
Inom kognitiv semantik förklaras positionsverbens prototypiska betydelse med att de går att härleda till människans tre huvudsakliga positioner. Det finns således en antropocentrisk grund till verbens betydelse och användning. Verbens antropocentriska bas kan beskrivas på följande sätt (Van Oosten I984; Lemmens 2002):

- staan/stå: människans kanoniska position är vertikal. Hos en stående människa är den vertikala positionen i fokus, dvs. människans höjd. Människan håller sig upprätt med egen fysisk kraft (+ kontroll).

- liggen/ligga: inte människans kanoniska position. Hos en liggande människa är den horisontella positionen i fokus, dvs. människans längd, inte höjd. Människan använder inte sin fysiska kraft (- kontroll).

- zitten/sitta: en position mellan stå och ligga. Människan använder sin fysiska kraft för att hålla sig upprätt i sittande position. Detta drag är mindre framträdande i jämförelse med stående position men mer framträdande i jämförelse med liggande position.

Verben har utifrån dessa prototypiska betydelser fått en utvidgad betydelse där positionsverben återger bl.a. icke-mänskliga subjekts position. Detta gör att positionsverben används mycket frekvent i nederländska och svenska (Lemmens \& Perrez 20Iо, Allén I97I). Ur följande exempel i (4.7) kan man härleda verbets antropocentriska grund $\mathrm{i}$ användningen av verbet med ett icke-mänskligt subjekt som i (4.8).

(4.7a) Flickan ligger i sängen. (mänsklig position)

$(4.7 \mathrm{~b})$ Het meisje ligt in bed.

(4.8a) Besticken ligger i lådan. (icke-mänskligt subjekt där dess rumsliga position anges)

(4.8b) Het bestek ligt in de la.

Positionsverbet ligga/liggen anger subjektets befintlighet på en plats och anger samtidigt en specifik position. Valet av positionsverb kan säga något om det icke-mänskliga subjektets utseende/ form eller funktion som i (4.8) där bestickets längd är i fokus vilket 
hänger ihop med det mänskliga subjektets position i (4.7). På en fråga var ett föremål finns anges ofta föremålets rumsliga position med något av positionsverben stå, ligga, sitta såsom $\mathrm{i}$ - waar is het boek?/var är boken?, - het staat op het rekjelden står på byllan.

I följande avsnitt beskrivs positionsverbens användning i nederländska och svenska mer ingående baserat på tre semantiska användningsområden som beskrivits för nederländskan i två artiklar av Lemmens \& Perrez (20I0) och De Knop \& Perrez (20I4).

\section{Positionsverbens semantiska nätverk i nederländska och svenska}

Begreppen figur och bakgrund används i beskrivningen av positionsverben som analysredskap. Figur och bakgrund används för att beskriva vad som fokuseras i satsen. Dessa termer anger hur något lyfts fram (figur) i förhållande till något annat som utgör referenspunkten (bakgrund). Figuren kan vara rörlig men inte nödvändigtvis medan bakgrunden gärna är fast (Talmy 2000:26; Vogel 20I I:48) såsom i soffan står på golvet. Soffan är här figuren och golvet är bakgrunden. Talmy (2000:3 I 2) anger att figur och/eller bakgrund kan vara en mängd av något eller ett område såsom i floden flöt utmed bergssidan. Här är floden figur och beskrivs i relation till bakgrunden bergssidan.

Man kan urskilja tre semantiska användningsområden vad gäller positionsverben: människans kroppsliga position när en människa konkret står, ligger och sitter, befintlighet som refererar till positionen en människa, ett djur eller entitet, (figur), har i förhållande till en konkret plats, exempelvis en låda, ett skåp eller golv (bakgrund) och metaforisk användning där figur och/ eller bakgrund har en abstrakt betydelse, illustrerat i (4.9), (4.10) respektive (4.II). ${ }^{2}$

(4.9a) Kvinnan sitter på stolen. (mänsklig position)

(4.9b) De vrouw zit op de stoel.

(4.Ioa) Gaffeln ligger på bordet. (befintlighet)

(4.Iob) De vork ligt op tafel.

(4.I Ia) Kollegorna stod maktlösa inför beslutet. (metaforisk användning)

(4.I Ib) De collega's stonden machteloos tegenover het besluit. 
I (4.9) är både figur och bakgrund konkreta med antroprocentrisk position i fokus. I (4.I0) är också figur och bakgrund konkreta men figuren, dvs. gaffeln, är ett icke-mänskligt subjekt vars position går att koppla till mänsklig position, jfr (4.8). Gaffelns placering ses ur ett horisontellt perspektiv och därför används verbet ligga/liggen. I (4.I I) är figuren (=kollegorna) konkret medan bakgrunden (=beslutet) är abstrakt och användningen av positionsverbet kan beskrivas som metaforisk. Vidare kan noteras att betydelsen mänsklig position och befintlighet kan förekomma samtidigt. På frågan: - var är mamma? kan svaret bli: - hon sitter $i$ vardagsrummet. Troligen sitter hon i vardagsrummet men svaret uttrycker framför allt att mamma befinner sig i vardagsrummet. Beskrivningen av positionsverben kommer att följa indelningen $\mathrm{i}$ ovan nämnda användningsområden.

Beskrivningen av positionsverben är baserad på s.k. föreställningsscheman som är en av grundpelarna i den kognitiva semantiken. I kognitiv semantik menar man att våra kroppsliga erfarenheter påverkar hur vi tänker om olika företeelser och dessa kroppsliga erfarenheter skapar mönster. Dessa mönster används om och om igen i förståelsen av vår omvärld och kallas föreställningsscheman. Föreställningsscheman bildas främst av erfarenheter som kommer från synsinnet, hörselsinnet och känselsinnet (Vogel 20I I:5 I). Man kan alltså säga att tanken är kroppsligt förankrad och det kan vi se i språket. Ett föreställningsschema som spelar en framskjuten roll i beskrivningen av positionsverben är behållare-schemat (containment). Lakoff och Johnson ( I980:29) skriver följande om behållare-schemat:

We are physical beings, bounded and set off from the rest of the world by the surface of our skins, and we experience the rest of the world as outside us. Each of us is a container, with a bounding surface and an in-out orientation. We project our own in-out orientation onto other physical objects that are bounded by surfaces. (...). Rooms and houses are obvious containers. Moving from room to room is moving from one container to another, that is, moving out of one room and into another.

I behållare-schemat är kroppen en behållare men det kan även vara konkreta föremål eller platser i relation till den egna kroppen såsom $\mathrm{i}$ kvinnan gick in $i$ den stora salen. Kroppen kan även vara 
en behållare för känslor som exempelvis sorg, glädje och ilska. Andra behållare som Lakoff och Johnson nämner är abstrakta såsom händelser, aktiviteter och tillstånd som i han låg $i$ koma (1980:30-32). Behållare-schemat tillsammans med kontakt-schemat är relevant vad gäller verben zitten och sitta (Lemmens 2002). För att använda termerna figur och bakgrund kan man säga att figuren har nära kontakt med bakgrunden för zitten (Lemmens 2002:I08). Det går även att applicera på svenskans sitta såsom i Kroken (figuren) sitter $i$ väggen (bakgrunden).

\section{Stå-staan}

Människans kroppsliga position refererar till en människas (men även i viss mån djur) stående position i sin prototypiska användning av stå och staan. Människans position är således vertikal och hon håller sig upprätt med egen kraft (+ kontroll), illustrerat i (4.I2) och (4.I3).

(4.I 2) Det står två kunder vid kassan.

(4.I3) Er staan twee klanten aan de kassa.

I dessa exempel beskrivs en konkret stående position. Denna kroppsliga, konkreta och mänskliga position kan utvidgas till befintlighet och referera till föremål stående på sin bas eller där föremålet har ben som exempelvis en stol. Människans stående position förefaller vara en av de främsta anledningarna till verbets utvidgade betydelse till icke-mänsklig befintlighet tvärspråkligt sett (Newman 2002). Här ligger fokus främst på föremålets bas, precis som människans bas är fötterna, se (4.I4) och (4.I 5), och inte på själva vertikaliteten. Viberg menar att svenskans stå anger att objektet eller föremålet typiskt har stöd underifrån (2013:I47). Jakobsson benämner detta "funktionellt upp" som innebär att när föremål är placerade med ovansidan uppåt och klara att tas i bruk används stå (I996:29). Detta stämmer även för nederländskans staan (Lemmens \& Perrez 20I2), se (4.I4) och (4.I5).

(4.I 4) Stolarna står i köket.

(4.I 5) De stoelen staan in de keuken. 
I (4.I4) och (4.I 5) är sittytan den funktionella sidan på stolen. Om stolarna ligger ner får det en speciell betydelse exemepelvis att någon har knuffat omkull dem: stolarna ligger $i$ köket. Jakobsson menar att stå och ligga fungerar som ett dikotomiskt par och om vi betraktar stolarna som liggande ses positionen istället som "icke funktionellt upp" (I996:35). Stå och staan blir på så vis den omarkerade positionen i (4.I4) och (4.I 5 ) och gäller allmänt för kategorin möbler. Att det handlar om basen eller stöd underifrån ser man även i exemplet tallriken står på bordet/het bord staat op tafel. Det handlar här också om att föremåls funktionella sida aktiveras i användningen av stå-staan (Jakobsson I996; Lemmens \& Perrez 20I2; Viberg 20I3:I46). Detta kan appliceras på bruksföremål i allmänhet såsom flaskor, koppar, datorer m.m. då deras normala position är stående. I jämförelse med ovan exempel får endast vertikalitet för stå-staan relevans när föremålets bas/funktion inte är i fokus såsom i följande exempelmeningar (4.I6) och (4.I7).

(4.I6) Tallrikarna står i diskstället.

(4.I7) De borden staan in het afdruiprek.

Tallrikens vertikala position är i fokus när de står på högkant $\mathrm{i}$ ett diskställ eftersom detta vanligen inte är tallrikens funktionella position. Tallrikens bas och funktionella sida är den centrala betydelsen vilket återges när tallrikarna står på bordet. För vissa föremål saknas en bas och då spelar dimensioner som längd och bredd en roll. Ett exempel på detta är en bok som inte har en funktionell sida. Den kan både stå och ligga beroende på var den placeras. I en bokhylla står den vanligen och på bordet ligger den (Lemmens \& Perrez 2012).

I nederländska förekommer även en användning av staan för att ange stor kvantitet. Samtidigt är föremålets funktionella sida fokuserad, dvs. det är burkarna som står som i satsen de kast stond vol potjes 'skåpet var fullt av burkar/?skåpet stod fullt av burkar'. I svenskan kan även verbet vara användas. Att det är fokus på föremålets funktionella sida blir tydligt vid en jämförelse med konstruktionen de weg lag vol met takken 'vägen låg full med grenar' där en gren inte har en funktionell sida utan dess längd är i fokus vilket föranleder användningen av verbet liggen/ ligga, se avsnittet om liggalliggen. 
Stå-staan kan även användas för att ange bokstävers, siffrors, teckens position i skriftligt material såsom i brev, texter och diagram eller på sidor, webbsidor eller tavlor, se (4.I8) - (4.2I).

(4.I8) Hennes adress stod i telefonkatalogen.

(4.I9) Haar adres stond in de telefoongids.

(4.20) Det står på sida 5 i boken.

(4.2I) Het staat op pagina 5 in het boek.

Denna användning av stå/staan förekommer i alla germanska språk förutom i engelska (Viberg 20I3: I 57). I dessa kontexter uppfattas bokstäver och siffror som stående på en linje. I (4.20) och (4.2I) är det inte bokstäver eller siffror som fokuseras utan allmän skriftlig information av något slag. Text kan även "stå" på en byggnad: företagsnamnet stod på byggnaden/de naam van het bedrijf stond op het gebouw. Det finns en skillnad mellan svenska och nederländska beträffande bilder och foton där nederländskan använder staan medan svenskan använder ett neutralt verb: op de foto staan - vara med på bild.

I nederländska kan staan även användas i värderande uttryck som i (4.22).

(4.22) Dat rokje staat je goed.

*Den kjolen står dig bra

'Den kjolen klär dig'

Van Oosten (I984) menar att detta hänger ihop med hur människan bär upp kläder, dvs. stående. Då syns klädernas passform. I svenska skulle ovanstående mening kunna skrivas om antingen med sitta eller med passa, jfr. 4.23) och (4.24):

(4.23) Den kjolen sitter bra (på dig).

(4.24) Den kjolen passar dig bra.

I (4.23) används positionsverbet sitta och man kan se det som att personen (eller del av personen) 'sitter' snyggt i klädesplagget. Vi kommer tillbaka till detta under avsnittet om sitta-zitten, se $(4.64)$.

Metaforisk användning beträffande stå-staan refererar till en människas position även när själva positionen är icke-fokuserad eller inte ens relevant (Lemmens \& Perrez 2010:320), men 
däremot finns kopplingen till att ha kontroll och använda fysisk kraft till verbet (Newman 2002:I7). Detta illustreras i (4.25) och $(4 \cdot 26)$.

(4.25) Vi måste stå för det vi säger.

(4.26) We moeten staan voor wat we zeggen.

I (4.25) och (4.26) kan man härleda den prototypiska betydelsen hos stå-staan ur kontroll och kraft. Ytterligare exempel är: Stå bakom något/någon - Achter iets/iemand staan, Stå fast vid något - Stå för sina principer - Voor jouw principes staan. Vidare finns det flera konstruktioner där nederländskan använder staan och svenskan liggen för att uttrycka samma sak: er staat er goed/ slecht voor respektive Det ligger braldailigt till. Ytterligare exempel på när svenskans stå och nederländskans staan kan kopplas till kraft och t. o. m. framgång är uttrycket något står och faller med det-daarmee staat of valt het. Här kopplas att förbli upprätt till framgång och att falla till misslyckande.

\section{Ligga-liggen}

Människans kroppsliga position för liggen och ligga refererar till en människas (och för vissa djur) liggande position vilket dock inte är hennes kanoniska position. Den prototypiska betydelsen innebär att fokus ligger på horisontell position och att en liggande människa inte använder sin kraft (- kontroll), såsom i (4.27) och (4.28).

(4.27) Barnet ligger i sängen.

(4.28) Het kind ligt in bed.

Befintlighet som betydelsedomän har horisontell position i fokus och framför allt om föremålet saknar en bas och är löst till sin struktur såsom kläder, dukar, papper, illustrerat i (4.29) och $(4 \cdot 30) .^{3}$

(4.29) Servetten ligger på bordet.

(4.30) Het servet ligt op tafel.

En servett är förhållandevis lös till sin struktur och kan vikas eller knögglas ihop och har därmed ingen typisk bas. Av den 
anledningen används liggalliggen för att ange horisontell position. Att den horisontella positionen är i fokus ser man även i exempelmeningen med bestick i (4.8) Besticken ligger i lådan. De varken står eller sitter men de kan ligga på exempelvis bordet, eftersom ingen naturlig funktionell sida existerar. Ett annat exempel är det låg en massa grenar på vägen/er lagen allemaal takken op de weg. En gren skulle kunna stå ut från trädets stam men i detta fall befinner sig grenarna/de takken på marken. De har förlorat sin funtionella, naturliga position och befinner sig på marken. Även för föremål eller entiteter som består av flera delar eller partiklar ligger fokus på horisontell position såsom i (4·3I) och (4.32).

(4.3I) Det ligger smulor på bordet.

(4.32) Er liggen kruimels op tafel.

I (4.3I) och (4.32) impliceras att figuren (smulor/kruimels) ligger utspridda på ett oordnat sätt (jfr. med uttrycket ligger och skräpar).

Användningen av ligga-liggen gäller i det följande runda eller symmetriska föremåls befintlighet som varken kan definieras utifrån horisontell eller vertikal position (Lemmens \& Perrez 20I0:323; Lemmens \& Perrez 20I2). Detta kan exemplifieras i en kontext där figuren är en boll mot bakgrunden gräs eller ett äpple på ett bord, se $(4.33)$ och $(4 \cdot 34)$.

(4.33a) Bollen ligger i gräset.

$(4.33 \mathrm{~b})$ De bal ligt in het gras.

(4.34a) Äpplet ligger på bordet.

(4.34b) De appel ligt op tafel.

Svenskans ligga kan även användas för att beskriva olika sorters föremåls position i ett mindre, delvis slutet utrymme. Det s.k. behållare-schemat aktiveras, jfr. (4.35) och (4.36).

(4.35) Isbiten ligger i glaset. (delvis slutet utrymme)

(4.36) Plånboken ligger i väskan. (slutet utrymme)

I (4.35) och (4.36) är det inte främst föremålets form som föranleder användningen av ligga i de svenska meningarna utan att de befinner sig i ett slutet eller delvis slutet utrymme (containment). Exempelmeningar som nycklarna ligger i fickan visar att varken 
föremålets fasthet eller konsistens spelar roll. I nederländska är det positionsverbet zitten som aktiveras hos behållare-schemat. I ovanstående exempelmeningar (4.35) och (4.36) aktiveras således zitten vilket diskuteras under avsnittet om sitta-zitten. Svenskans användning av ligga kallar vi behållare-ligga.

Ligga-liggen används för att ange ett områdes, stads eller byggnads befintlighet på en horisontell linje eller skala, dvs. en sorts geografisk position. Man kan också se det som att ett område är täckt av en stad eller byggnad, illustrerat i (4.37-4.40).

(4.37) Skolan låg framför oss.

(4.38) De school lag voor ons.

(4.39) Stockholm ligger vid Mälaren.

(4.40) De haven van Rotterdam ligt aan de Noordzee.

'Rotterdams hamn ligger vid Nordsjön'

I (4.37) är det inte själva skolan som konkret byggnad som fokuseras utan en geografisk position, en plats, där man befinner sig i skolan. Jakobsson menar att svenskans ligga fungerar som omärkt positionsverb för angivande av geografisk position (I996:35). ${ }^{4}$ Denna användning är frekvent i svenskan (Viberg 20I3:I 53) vilket även stämmer för nederländskan. Vid en jämförelse mellan ligga-liggen och stå-staan används det senare för att fokusera på själva byggnaden såsom i (4.4I) och (4.42).

(4.4I) Det står ett hus på berget.

(4.42) Er staat een huis op de berg.

I (4.4I) och (4.42) är det inte en allmän geografisk position som fokuseras utan byggnadens konkreta bas eller funktionella sida som är i fokus och då används just stå-staan. Enligt Viberg är användningen av svenskans stå i kombination med byggnader o.dyl. mindre frekvent (20I3:I48). I vissa fall förefaller byggnadens funktion i kombination med geografisk position att göra sig gällande snarare än byggnadens bas. I dessa konstruktioner används ligga framför stå som i biblioteket ligger $i$ innerstan. På nederländska är både zijn 'vara' och liggen möjliga i denna kontext: de bibliotheek is/ligt in de binnenstad. För båda språken aktiveras för ligga/liggen också en skala som rör kvantitativa 
aspekter i exempel som Lönen ligger runt 30 ooo /Het salaris ligt rond de 30000 .

Den utvidgade betydelsen av ligga-liggen till den metaforiska betydelsedomänen gäller ofta abstrakt bakgrund såsom ansvar, problem, tillstånd. I den metaforiska domänen märks de största skillnaderna mellan språken, se (4.43) och (4.44).

(4.43) Zij winnen en wij liggen eruit. $^{5}$

'De vinner och vi är utslagna'

(4.44) Vi vann mycket pengar men vi ligger lågt med beloppet. 'Wij hebben veel geld gewonnen maar we houden ons gedekt over het bedrag'

I verbets antropocentriska betydelse ingår elementet - kontroll (dvs. vid liggande position finns kopplingar till inaktivitet och negativa händelser) vilket skulle kunna förklara de metaforiska uttrycken i (4.43) och (4.44). Vid en närmare betraktelse av den metaforiska domänen med ligga och liggen kan vissa uttryck benämnas metaforisk behållare (jfr. Lemmens \& Perrez 2010:328), såsom i $(4 \cdot 45)-(4 \cdot 47)$.

(4.45a) Det ligger inte i hans natur.

$(4.45$ b) Het $z i t$ niet in zijn natuur/het ligt niet in zijn aard.

(4.46a) Problemet ligger hos henne.

(4.46b) Het probleem zit/ligt bij haar.

(4.47a) Det ligger mig i fatet.

(4.47b) Het zit me dwars.

'Det retar mig'

(4.48a) Det kan aldrig ligga på henne att lösa problemet.

$(4.48$ b) Het kan nooit aan haar liggen.

I exemplen ovan aktiveras ibland både liggen och zitten i nederländskan vilket inte gäller för svenskan. I (4.48) anger liggen/ ligga betydelsen av att problemet o.dyl. är som en tyngd för det mänskliga subjektet. Den metaforiska behållaren kan kopplas till behållare-ligga som nämnts tidigare för svenskan under avsnittet om befintlighet (se exempelvis $(4 \cdot 35)-(4 \cdot 36)$.

För ligga-liggen kan en tidslinje som beskriver en abstrakt tidsaspekt aktiveras. Denna tidsaspekt i form av en abstrakt 
tidpunkt kan ligga bakom eller framför människan som i (4.49) eller för att beskriva en händelse i nuet som i (4.50).

(4.49a) Det ligger i det förgångna

$(4.49 \mathrm{~b})$ Het ligt in het verleden.

(4.50) Det ligger i tiden.

'Het is iets van deze tijd'

\section{Sitta-zitten}

Människans kroppsliga position för zitten och sitta refererar till en människa (eller djur) i sittande position. Den prototypiska betydelsen innebär en position mellan stå och ligga. Människan använder sin kraft för att hålla sig upprätt i sittande position. Detta drag är mindre framträdande i jämförelse med stående position men mer framträdande i jämförelse med liggande position. Sitta-zitten illustreras i $(4.5 \mathrm{I})-(4.54)$.

(4.5 I) Sitt fint! (till en hund)

(4.52) Ga zitten! (till en människa eller hund)

(4.53) Familjen sitter till bords.

(4.54) De familie zit aan tafel.

Befintlighet som betydelsedomän kan relateras till framför allt två föreställningsscheman: behållare och kontakt (se avsnittet om positionsverbens semantiska nätverk).

Behållare-schemat i relation till ett mänskligt subjekt uppfattas som att en människa (figuren) befinner sig i en grupp av människor eller ett sammanhang. Detta kan beskrivas som deltagande i å ena sidan ett formellt sammanhang där zitten-sitta refererar till att inneha en befattning, exempelvis i en styrelse eller regering, och å andra sidan deltagande under tvång, som i ett fängelse, jfr. (4.55) (4.56) med (4.57) - (4.58).

(4.55) Det sitter Io personer i styrelsen.

(4.56) Er zitten Io personen in het bestuur.

(4.57) Förbrytaren sitter i fängelse. ${ }^{6}$

(4.58) De misdader zit in de gevangenis.

Exempelmeningarna ovan anger befintlighet även om man kan förmoda att en konkret sittande position förekommer i exempelvis 
en styrelse. Det är dock inte i fokus. Här aktiveras betydelsen deltagare i ett sammanhang. ${ }^{7}$ En centralstation eller ett väntrum fyller inte den funktionen och en sats såsom det sitter mycket folk $i$ stationshallen anger ett tydligt konkret sittande, inte deltagande i ett sammanhang av något slag som i $(4.55)-(4.58)$. I presenteringskonstruktionerna de finns många människor $i$ stationshallen/er zijn veel mensen in de stationshal används finns respektive zijn för att ange befintlighet och är den omarkerade konstruktionen.

Att det inte främst handlar om mänsklig position i exemplen $(4.55)-(4.58)$ blir tydligt i en jämförelse med exempel där svenska och nederländska skiljer sig åt. I exempelmeningarna i (4.59) och i (4.60) använder svenska gå $i$ skolan medan nederländska använder op school zitten, jfr.

(4.59) De gàr i skolan.

(4.60) Ze zitten op school.

'*De sitter på skolan’

I dessa satser handlar det inte om ett konkret sittande i skolan utan att eleverna under en längre period befinner sig i en skolmiljö. Svenska kan använda verbet gå för att uttrycka befintlighet över tid på en plats: eleverna befinner sig i skolvärlden under en längre period och bruket av rörelseverbet gå kan ses som en abstrakt rörelse i tiden. Här aktiveras tidschemat i svenska, inte behållare-schemat. Nederländskans positionsverb zitten fungerar i (4.60) som exemplen ovan i $(4.55)-(4.58)$ och uttrycker befintlighet i en grupp av människor i ett formellt sammanhang, dvs. behållare-schemat aktiveras.

Icke-mänskliga subjekt som utgör konkreta föremål eller icke fasta entiteter som vätskor, socker eller sand aktiverar nederländskans zitten när bakgrunden är någon sorts behållare. I (4.6I4.63) aktiveras således behållare-schemat.

(4.6ra) Er zit wijn in het glas.

(4.6I $\mathrm{Ib})$ Det finns/är vin i glaset.

(4.62a) Het boek zit in de tas.

(4.62b) Boken ligger i väskan.

(4.63a) De muntjes zitten in mijn zak.

(4.63b) Mynten ligger i fickan. 
Tydligt är att behållare-schemat inte föranleder användningen av sitta i svenskan när det gäller konkreta föremål i ett slutet utrymme. Istället aktiverar behållare-schemat ligga i $(4.62 \mathrm{~b})-(4.63 \mathrm{~b})$ ovan. I avsnittet om ligga har denna användning fått benämningen behållare-ligga. För flytande vätskor och andra icke fasta entiteter används existensverben finnas eller vara, som i (4.6 I b), för att ange befintlighet.

Lemmens (2002) anger att zitten i nederländska kan aktiveras i en utvidgad betydelse relaterat till kläder som i (4.64).

(4.64) Deze jurk zit lekker/fijn/goed.

Detta beskrivs som att zitten uttrycker att personen (eller del av personen) 'sitter' bekvämt/snyggt i klädesplagget (Lemmens 2002:II3-II4). För dessa konstruktioner aktiveras även det s.k. kontakt-schemat där kläderna/tyget har kontakt med människans kropp. Här överensstämmer nederländska med svenska, jfr. (4.65).

(4.65) Den här klänningen sitter bekvämt/snyggt/bra.

Konstruktionen i (4.64) går att jämföra med bruket av staan i exempelmeningen i (4.22): dat rokje staat je goed. En snarlik konstruktionen är nederländskans deze stoel zit lekker' '*den här stolen sitter bekvämt' som anger att stolen är bekväm men även att personen i stolen sitter bekvämt. Stolen blir en sorts förlängning av kroppen. Satsen kan parafraseras på svenska med konstruktionen den här stolen är bekväm att sitta $i$.

Kontakt-schemat, som nämndes ovan, kan aktivera zitten-sitta. Det handlar om konkreta föremåls kontakt, dvs. kontakt mellan figur och bakgrund som båda är konkreta, illustrerat $i$ $(4.66)-(4.67)$.

(4.66a) De vlekken zaten nog op de broek.

(4.66b) Fläckarna satt forfarande på byxorna.

(4.67a) Hier zit er nog wat!

(4.67b) Här sitter det lite kvar!

Vi kan benämna detta kontakt-zitten/sitta. Jacobsson (I996:3639) hänvisar till föreställningschemat koppling i betydelsen 
angjord för svenskans sitta i satser som i $(4.66 a)-(4.67 b)$ med negativ funktion eftersom fläckarna är ett oönskat resultat av att någon har spillt exempelvis dryck eller mat. Viberg benämner detta attachment för svenskan (20I3:I 59 ff). I uttryck med sitta fast och vastzitten aktiveras också kontakt-schemat: hon sitter fast $i$ bilkön/zij zit in de files vast. I vissa fall tycks även behållare-schemat vara aktiverat samtidigt som i (4.68).

(4.68a) Nyckeln sitter i låset.

(4.68b) De sleutel zit in het slot.

Exempelmeningarna i (4.68) anger att ett föremål sitter fast i ett slutet eller delvis slutet utrymme. Här kan man med fog hävda att främst kontakt-schemat är aktiverat.

I svenskan kan både sitta och hänga användas när figuren har kontakt med bakgrunden. I nederländskan används endast hangen 'hänga', jfr. (4.69).

(4.69a) Lappen sitter/hänger på anslagstavlan.

$(4.69 \mathrm{~b})$ Het papiertje hangt op het prikbord.

I (4.69a) och (4.69b) är inte behållare-schemat aktiverat till skillnad mot (4.68). I nederländska och svenska kan dock zitten-sitta användas om kontakten mellan figuren och bakgrunden är heltäckande, vilket alltså inte är fallet i (4.69) där lappen inte sitter tätt mot bakgrunden (=anslagstavlan). I (4.70) är figuren, etikett, limmad på bakgrunden, flaskan.

(4.70a) Het etiketje zit op de fles.

(4.70b) Etiketten sitter på flaskan.

Kontakt-schemat är även aktiverat i exempelmeningen er zat bloed op de lakens - det fannslvar blod på lakanen. Den nederländska meningen kan formuleras på följande sätt: Vätskan X har fastnat på underlaget Y. Detta påminner om bruket av behållare-zitten $\mathrm{i}$ (4.6I) där entiteten också är en vätska. Återigen blir det tydligt att svenskan inte använder sitta i relation till icke fasta entiteter utan istället används verben finnas eller vara.

I relation till kontakt-schemat kan även betydelsen omslutning nämnas (Van Staden, Bowerman \& Verhelst 2006:498). Det 
föranleder bruket av både sitta och zitten i relation till exempelvis ett halsband som i halsbandet sitter härt/tätt runt halsen/de ketting zit strak om zijn nek. En halskedja hänger vanligtvis runt halsen men om det är mer kontakt mellan hals och halsband än vid en löst hängande halskedja aktiveras zitten-sitta.

En annan skillnad mellan nederländska och svenska utgör betydelsen negativt utrymme. Van Staden, Bowerman \& Verhelst (2006:497) benämner detta negative space för nederländskan, som i (4.7Ia).

(4.7 Ia) Er zit een gat in haar broek.

(4.7 Ib) Det finns/är ett hål i hennes byxor.

Figuren i (4.7 Ia), dvs. själva hålet, är det negativa utrymmet vilket föranleder bruket av zitten medan svenskan använder något av existensverben finnas eller vara i (4.7 Ib).

I nederländskan och svenskan kan även vistelse, dvs. att befinna sig över tid på en viss geografisk plats, uttryckas med zitten-sitta som i (4.72).

(4.72a) Ik zit al een tijdje in de hoofdstad.

(4.72b) Jag sitter sedan en tid tillbaka i huvudstaden.

I (4.72a) och $(4.72 \mathrm{~b})$ betyder zitten-sitta att befinna sig på en plats under en viss tid. Den svenska satsen i $(4 \cdot 72 \mathrm{~b})$ är mer markerad och det handlar inte om neutral befintlighet. Jakobsson nämner att denna användning refererar till att befinna sig på en uppehållsort under utförandet av uppdrag (I996:5I). Det är alltså återigen inte fokus på ett konkret sittande och kan jämföras med exempelmeningarna i $(4.55)-(4.58)$. Dock förekommer denna konstruktion mer produktivt i nederländskan såsom i de familie zit op vakantie in Engeland 'familjen har semester i England/är på semester i England' eller zij zit in New York voor zaken 'hon befinner sig i New York i affärer'.

Fysiskt förnimmelse såsom smärta kan också kopplas till användningen av sitta och zitten (se också Jakobsson 1996). Känslor är abstrakta men i detta fall handlar det om konkret, fysisk smärta som i exempelmeningarna för svenska i (4.73) och för nederländska i (4.74), inte om metaforisk betydelse. 
(4.73a) Var sitter smärtan?

(4.73b) Smärtan sitter i magen.

(4.74a) Waar zit de pijn?

(4.74b) De pijn zit in de maag.

I dessa exempelmeningar är kroppen behållaren där smärtan finns i någon kroppsdel, som här i magen. Detta kan även gälla ett specifikt organs placering i kroppen: lungorna sitter bakom bröstbenet/de longen zitten achter het borstbeen.

Metaforisk betydelsedomän är produktiv för båda språken. Många konstruktioner kan benämnas metaforisk behållare där en eller två entiteter är abstrakta (se Lemmens \& Perrez 20I0:328). Få överensstämmelser finns mellan nederländska och svenska i bruket av positionsverb här. Vidare används sitta-zitten för att uttrycka känslor och kunskap av olika slag i båda språken. I vissa fall använder nederländskan zitten och motsvarigheten på svenska konstrueras med något av de andra två positionsverben, med vara eller en annan konstruktion. Det motsatta förhållandet förekommer också. Därför presenteras exemplen per språk för att ge en bild av hur zitten respektive sitta kan användas men den är långt ifrån heltäckande. I (4.75a) - (4.80oa) ges exempel med nederländskans zitten med de svenska översättningarna $\mathrm{i}$ $(4.75 \mathrm{~b})-(4.8 \mathrm{ob})$.

(4.75a) Het zit er dik in.

(4.75b) 'Det är mycket väl möjligt'

(4.76a) Het zit in de familie.

(4.76b) 'Det ligger i släkten'

Typiskt för metaforisk domän är att konstruktionerna ofta är idiom och har en betydelse som inte går att härleda ur uttryckets olika delar, dvs. uttrycket är inte genomskinligt (Lemmens \& Perrez 2010, Verstraten 1992). De nederländska exempelmeningarna med zitten i $(4.77)-(4.80)$ är idiom.

(4.77a) Peter heeft Sandra hoog zitten.

$(4.77 \mathrm{~b})$ 'Peter håller Sandra högt'

(4.78a) De conferentie zit erop.

(4.78b) 'Konferensen är avslutad'

(4.79a) Op het eerste zicht zie ik dat niet zitten. 
(4.79b) 'Till att börja med tror jag inte på det'

(4.80a) Daar zit ik nog mee.

(4.80b) 'Det grubblar jag fortarande på'

Följande exempel med sitta i $(4.8$ Ia $)-(4.85$ a) är representativa för den metaforiska domänen i svenskan. I $(4.8 \mathrm{I} b)-(4.85 \mathrm{~b})$ ges de nederländska översättningarna.

(4.8 Ia) Bekännelsen satt långt inne.

(4.8 Ib) 'De bekentenis kwam er met moeite uit'

(4.82a) Det sitter i väggarna.

(4.82b) 'Dat is traditie'

(4.83a) $\mathrm{Nu}$ sitter vi verkligen i klistret.

$(4.83 \mathrm{~b})$ ' $\mathrm{Nu}$ zitten we echt in de puree'

(4.84a) Det skulle sitta fint!

(4.84b) 'Dat zou lekker zijn'

(4.85a) Det sitter som en smäck!

$(4.85 \mathrm{~b})$ 'Dat heb ik goed onder de knie'

\section{Vara-zijn}

Det framgår i beskrivningen av positionsverben i svenska och nederländska hur dessa används för att beskriva mänskliga subjekts och föremåls/entiteters befintlighet. Det finns dock ett flertal kontexter när verbet zijn 'vara' kan användas. Van Staden, Bowerman \& Verhelst (2006:494) anger att nederländskans zijn istället för staan eller liggen används vid var-frågor, se $(4.86)-(4.87)$.

(4.86) Waar zijn mijn schoenen?

'Var är mina skor?'

(4.87) Waar is mijn bril?

'Var är mina glasögon?'

I (4.86) och (4.87) saknas en bakgrund som anger var figuren är förankrad i rummet i jämförelse med en deklarativ sats där antingen staan som i mijn schoenen staan in de hal 'mina skor står i hallen' används eller liggen som i mijn bril ligt op tafel 'mina glasögon ligger på bordet'. De hal respektive tafel utgör bakgrunden i dessa satser. För svenskan fungerar både vara, stå respektive ligga i dessa satser, jfr. (4.88) och (4.89). 
(4.88) Var är/står mina skor?

(4.89) Var är/ligger mina glasögon?

Om bakgrundens storlek uppfattas som stor i förhållande till figuren blir bakgrunden irrelevant och då kan även zijn användas $\mathrm{i}$ vissa kontexter (Van Staden, Bowerman \& Verhelst (2006:495). Det stämmer även in på svenskan, jfr. (4.90).

(4.90a) Haar meubels zijn/staan nog in Berlijn.

(4.90b) Hennes möbler är/står fortfarande i Berlin.

I (4.90) är bakgrunden, Berlin, relativt stor i förhållande till möblernas position och bruket av ett positionsverbet staan-stå blir fakultativt.

I presenteringskonstruktioner har sitta och zitten inte utvidgad betydelse utan anger en konkret sittande position: det sitter många människor i väntrummetler zitten veel mensen in de wachtkamer. Om man endast vill ange att människor befinner sig i väntrummet används verbet vara respektive zijn, jfr. (4.9I).

(4.9Ia) Det är många människor i väntrummet.

(4.9 Ib) Er zijn veel mensen in de wachtkamer.

I en jämförelse mellan satserna i (4.9I) och (4.92) framgår att sitta respektive zitten har en annan funktion, jfr.

(4.92a) Hon sitter i regeringen.

$(4.92 \mathrm{~b}) \mathrm{Zij} z i t$ in de regering.

Exempelmeningarna i (4.92a) och (4.92b) anger att det mänskliga subjektet har en funktion och befinner sig i styrelsen för att utföra ett uppdrag och är det omarkerade verbet. Exempelmeningarna i (4.9 Ia) och $(4.9 \mathrm{Ib})$ anger endast befintlighet och om man byter ut vara respektive zijn mot sitta respektive zitten skiftar betydelsen till konkret sittande position.

\section{Sammanfattning}

Ur positionsverbens prototypiska antropocentriska användning kan många utvidgade betydelser härledas. De utvidgade betydelserna kan kopplas till domänerna befintlighet och metaforisk 
användning. Nederländska och svenska uppvisar både likheter och skillnader vad gäller dessa två domäner. Störst överlappande bruk kan observeras för nederländskans staan och svenskans stå. Föremålets funktionella sida och att det stöds underifrån aktiverar användningen av verbet. Vad gäller liggen - ligga är det den horisontella positionen som är i fokus vilket är kopplat till föremålets längd eller utbredning. Dock skiljer sig nederländskan och svenskan åt i det att behållare-schemat främst aktiveras för svenskans ligga, inte för nederländskans liggen. I nederländskan är det istället för zitten som behållare-schemat aktiveras i större utsträckning när föremålets bas inte främst är i fokus utan när föremålet/entiteten befinner sig i ett slutet utrymme som kan vara konkret eller abstrakt. I de fall svenskan inte använder sitta för motsvarande satser på nederländska tas ligga eller existensverb som finnas eller vara i bruk. I Vibergs undersökning av positionsverb i ett antal språk är det just de germanska språkens bruk av motsvarigheten till svenskans sitta i kombination med icke-mänskliga subjekt där språken uppvisar störst skillnader sinsemellan (2013:I 59). Verbens metaforiska betydelser skiljer sig dock störst åt mellan nederländska och svenska och som språkinlärare måste dessa uttryck ofta läras in som separata lexikala enheter.

\section{Noter}

I. De nederländska och italienska exempelmeningarna i detta avsnitt kommer från en artikel som diskuterar hur det nederländska språket som satellite-framed skiljer sig från italienskan som verb-framed (Ross 2016:78).

2. Det som har utsträckning i rummet och som kan observeras räknas som konkret, exempelvis människor, djur och saker. Det som inte har utsträckning i rummet räknas som abstrakt såsom känslor och tankar.

3. Lemmens (2002) benämner dessa entiteter non-rigid objects.

4. Van Staden, Bowerman \& Verhelst nämner att zitten i undantagsfall kan ange geografisk position såsom i de bakkerij zit op de hoek (="bageriet sitter på hörnet) 'bageriet ligger på hörnet'. Denna 
användning fungerar endast om figuren utgör en verksamhet som har en funktion (2006:499).

5. Eruit liggen kan även betyda vara $i$ onåd.

6. Om anstaltens namn anges används prepositinen på som i de sitter på Ulleråker.

7. Verben stå-staan och ligga-liggen har en liknande funktion i vissa lexikaliserade uttryck såsom i svenskans stå $i$ bostadskön, stå med på listan och ligga $i$ lumpen respektive i nederländskans op de lijst staan 'stå med på listan' och hij lag op de Veluwe 'han låg i lumpen på Veluwe'. I dessa satser är det uppenbart inte positionen det handlar om utan befintlighet i form av deltagande i ett specifikt sammanhang. 